\title{
Immunological and immunohistochemical analysis of rheumatoid nodules
}

\author{
NOBUYUKI MIYASAKA ${ }^{1}$ KAZUTO SATO, ${ }^{1}$ KAZUHIKO YAMAMOTO, \\ MAKOTO GOTO, ${ }^{3}$ AND KUSUKI NISHIOKA ${ }^{1}$
}

From the ${ }^{1}$ Division of Clinical Immunology, Institute of Rheumatology, Tokyo Women's Medical College, $\overrightarrow{\vec{\omega}}$ Tokyo, Japan; the ${ }^{2}$ Department of Medicine and Physical Therapy, Faculty of Medicine, Tokyo University; and the ${ }^{3}$ Division of Rheumatology, Tokyo Metropolitan Otsuka Hospital, Japan

SUMmARY An attempt was made to examine the pathophysiology of the rheumatoid nodule. N Significant amounts of interleukin 1-like activity and prostaglandin $E_{2}$ were detected in the supernatants from in vitro organ cultures of rheumatoid nodule tissue. When fresh (but not old) $\underset{\rightarrow}{\triangle}$ rheumatoid nodules were minced and cultured in vitro prominent outgrowths of cells were $\vec{z}$ observed. These cells expressed both HLA-DR and CD14 antigens but lacked conventional $\frac{\$}{3}$ differentiation antigens for T cells and B cells, suggesting that they are of monocyte-macrophage $\mathcal{S}$ origin. These data suggest that interleukin 1 and prostaglandin $E_{2}$ may be deeply involved in the $\vec{\oplus}$ formation of rheumatoid nodules.

Key words: rheumatoid arthritis, interleukin 1, prostaglandins.

Rheumatoid nodules occur in approximately $20 \%$ of patients with rheumatoid arthritis. ${ }^{1}$ These patients with rheumatoid arthritis tend to have high titres of rheumatoid factor. Histologically, a rheumatoid nodule is composed of three zones: an inner zone of central necrosis, a middle cellular palisading area, and an outer granulomatous area with perivascular infiltration of chronic inflammatory cells. ${ }^{12}$ The pathogenesis of rheumatoid nodules is not fully understood, though many factors, including proteolytic enzymes, ${ }^{3}$ trauma, ${ }^{4}$ immune complexes, ${ }^{5}$ and genetic factors, ${ }^{6}$ are believed to be involved.

Cytokines are indispensable for the physiological interaction of cells. Furthermore, abnormal production of these soluble factors may contribute to disordered immunoregulation in various autoimmune diseases like systemic lupus erythematosus and rheumatoid arthritis. ${ }^{7}$ Interleukin 1 , especially, has multiple biological activities that include the induction of fever by acting on the hypothalamus, induction of the acute phase reactants from the liver, activation of polymorphonuclear cells, and stimulation of interleukin 2 production by T cells. ${ }^{8}$ Of particular relevance to rheumatoid arthritis, interleukin 1 induces the production of prostaglan-

Accepted for publication 4 August 1988.

Correspondence to Dr Nobuyuki Miyasaka, Institute of Rheumatology, Tokyo Women's Medical College, NS Building, 2-4-1, Nishi-Shinjuku-ku, Tokyo, Japan 163. dins and collagenase from synovial cells. ${ }^{9}$ Ourळ examination of biopsied rheumatoid synovium indicated that interleukin 1 might be strongly involvedō in joint destruction in rheumatoid arthritis. ${ }^{10} \mathrm{We}^{\exists}$ therefore studied the production of cytokines and prostaglandin $E_{2}$ by rheumatoid nodules in an attempt to clarify the pathogenesis of these nodules.

\section{Patients and methods}

Nine patients (two men, seven women) with classical rheumatoid arthritis as defined by the Americano Rheumatism Association criteria ${ }^{11}$ were included in the study (Table 1). The duration of disease variedo from eight months to 12 years, and nodules were present from two weeks to one year. All subjectsor except patient 7 were seropositive for rheumatoidn factors, with titres ranging from $1 / 160$ to $1 / 5120$ on the haemagglutination test using sheep red blood ${ }_{0}^{\omega}$ cells sensitised with rabbit IgG (RAHA test). Onepatient was treated with $5 \mathrm{mg} /$ day of prednisolonec and one with $100 \mathrm{mg} /$ day of D-penicillamine; thees others received only non-steroidal anti-inflam matory drugs.

PREPARATION OF SAMPLES

Subcutaneous nodules were removed without complication from the olecranon region while patients were under local anaesthesia. The nodules were? 
Table 1 Patient profiles

\begin{tabular}{lcccccc}
\hline $\begin{array}{l}\text { Patient } \\
\text { No }\end{array}$ & Age & Sex & $\begin{array}{l}\text { ESR* } \\
(\mathrm{mm} / \mathrm{h})\end{array}$ & $R A-T^{*}$ & $R A H A^{*}$ & $\begin{array}{l}\text { Duration of } \\
\text { rheumatoid } \\
\text { nodules }\end{array}$ \\
\hline 1 & 58 & F & 103 & $1+$ & $1 / 1280$ & 2 to 4 wks \\
2 & 59 & M & 61 & $1+$ & $1 / 2560$ & 4 wks \\
3 & 38 & M & 13 & $1+$ & $1 / 5120$ & 4 wks \\
4 & 27 & F & 50 & $1+$ & $1 / 320$ & 12 mos \\
5 & 46 & F & 52 & $1+$ & $1 / 160$ & 12 mos \\
6 & 42 & F & 10 & $1+$ & $1 / 2560$ & 12 mos \\
7 & 60 & F & 55 & - & $1 /<40$ & 4 wks \\
8 & 55 & F & 84 & $1+$ & $1 / 640$ & 8 wks \\
9 & 43 & F & 26 & $1+$ & $1 / 1280$ & 3 mos \\
\hline
\end{tabular}

${ }^{*}$ ESR = erythrocyte sedimentation rate; RA-T=latex fixation test for rheumatoid factors; RAHA=haemagglutination test for rheumatoid factors.

immediately cut into pieces $3 \mathrm{~mm}$ in diameter. Some of the samples were washed extensively with RPMI 1640 (Gibco, Grand Island, NY, USA) and plated into 24-well culture plates (Sumitomo, Japan) with RPMI 1640 supplemented with $10 \%$ fetal calf serum (Gibco), 100 units $/ \mathrm{ml}$ penicillin, $100 \mu \mathrm{g} / \mathrm{ml}$ streptomycin, and $10 \mathrm{mM}$ HEPES buffer ( $N$-2hydroxyethylpiperazine- $N^{\prime}$-2-ethanesulphonic acid; Sigma, St Louis, MO, USA). Culture supernatants were harvested at various intervals and assayed for interleukin 1 , interleukin 2 , and interleukin 3 activities, as described below. The rest of the samples were embedded in OCT medium (Miles, Naperville, IL, USA), frozen in liquid nitrogen, and stored at $-70^{\circ} \mathrm{C}$. In some experiments rheumatoid nodules were minced with scissors and plated into 24-well tissue culture plates in $10 \%$ fetal calf serum-RPMI 1640. When cell outgrowths were observed during the culture period the cells were collected and examined for cell surface antigens and responsiveness to various stimuli, including mitogens and interleukin 2, as described below.

\section{ASSAYS FOR CYTOKINE ACTIVITY}

Interleukin 1 activity was measured by a thymocyte proliferation assay. ${ }^{12}$ Briefly, $5 \times 10^{5}$ thymocytes from $\mathrm{C} 3 \mathrm{H} / \mathrm{HeJ}$ mice (non-responders to lipopolysaccharide) were resuspended in RPMI 1640 with $10 \%$ fetal calf serum and plated in 96-well flat bottom tissue culture plates with a suboptimal dose of concanavalin A (Sigma, St Louis, MO, USA). Test samples or standard interleukin 1 (Genzyme, Boston, MA, USA) of various dilutions were added to the wells and incubated for 72 hours at $37^{\circ} \mathrm{C}$ in a $5 \%$ $\mathrm{CO}_{2}$ incubator. Cell proliferation was measured by the incorporation of tritiated thymidine, as previously reported. ${ }^{10}$ One unit of interleukin 1 was defined as the reciprocal of the dilution at which $50 \%$ of the maximum response was obtained accord- ing to the method described by Matsuchima et al. ${ }^{13}$ Maximum response was obtained when 10 units $/ \mathrm{ml}$ of standard interleukin 1 was used. To confirm interleukin 1 activity a growth inhibition assay using the melanoma cell line A375 was also employed. ${ }^{14}$ Briefly, A375 cells were plated into 96-well flat bottom culture plates $\left(1 \times 10^{4}\right.$ cells/well $)$ in Eagle's minimum essential medium supplemented with $10 \%$ fetal calf serum with various dilutions of test samples or recombinant interleukin 1 (kindly provided by Dr Y Hirai of Otsuka Pharmaceutical Co Ltd). After four days' incubation at $37^{\circ} \mathrm{C} 0.5 \%$ neutral red was added to each well. Neutral red incorporated in viable cells was extracted with ethanol after two hours of culture. The optical density of each well was measured at $540 \mathrm{~nm}$ by a multiscan photometer. One unit per millilitre represented the reciprocal of the dilution of samples causing $50 \%$ cytostasis or cytolysis after four days of culture. Complete cytostasis was usually obtained when $125 \mathrm{ng} / \mathrm{ml}$ of recombinant interleukin $1 \beta$ was used. In the experiments using the A375 cell line, samples with known interleukin 1-like activity were added to A375 cells with either polyclonal antihuman interleukin $1 \alpha$ antibody (OCT 303)(1:400 dilution), antihuman interleukin $1 \beta$ antibody (OCT 204) (1:400), or an equivalent dose of normal rabbit IgG to determine whether these antibodies neutralised the interleukin 1-like activity in the samples. These antibodies, raised by immunising rabbits with either recombinant interleukin $1 \alpha$ or interleukin $1 \beta$, were kindly provided by Dr Y Hirai of Otsuka Pharmaceutical Co Ltd. The antibodies have been described in detail elsewhere. ${ }^{15}$ Interleukin 2 activity was assayed using an interleukin 2 dependent mouse cytotoxic $\mathrm{T}$ cell line, B6. ${ }^{16}$ Interleukin 3 activity was measured using an interleukin 3 dependent mouse cell line, IC2, kindly provided by Dr Y Koyasu. ${ }^{17}$ Purified interleukin 2 (Nihon Kohtai, Japan) and a culture supernatant of WEHI-3 were used as standards in interleukin 2 and interleukin 3 assays respectively. Both interleukin 2 and interleukin 3 activities were calculated according to the method described by Gillis et al. ${ }^{18}$

PROSTAGLANDIN E ASSAY

Prostaglandin $E_{2}$ in the culture media was measured by a radioimmunoassay kit (New England Nuclear, Boston, MA, USA) after extraction and silicic acid column chromatography, as described previously. ${ }^{19}$ Results were expressed as pg of prostaglandin $E_{2} / \mathrm{ml}$ (SEM).

RESPONSE OF CELLS TO MITOGENS AND INTERLEUKIN 2

Cell outgrowths from rheumatoid nodules were 
collected and resuspended in RPMI 1640 containing $10 \%$ fetal calf serum. The cells were plated in 96-well tissue culture plates $\left(1 \times 10^{5}\right.$ cells/well $)$ and cultured with an optimal dose of either phytohaemagglutinin (Difco, MI, USA), concanavalin A (Sigma), Staphylococcus aureus Cowan I (Calbiochem, La Jolla, CA, USA), or interleukin 2 for 72 hours. Thymidine incorporation was measured as described above.

\section{IMMUNOHISTOCHEMICAL STAINING}

Frozen tissues or cell smears were fixed with acetone and stained by monoclonal antibodies, as described below. Anti-CD2 (reactive with T11), anti-CD3 (reactive with T3), anti-CD4, anti-CD8, anti-CD20 and anti-CD21 (both reactive with $B$ cells), anti- $I_{2}$ (reactive with HLA-DR antigens), and anti-CD11b and anti-CD14 (both reactive with monocytes and myelocytes) were all products of Coulter Immunology (Hialeah, FL, USA) and the gift of Japan Scientific Instrument Company (Tokyo, Japan). Briefly, samples were incubated with a specific monoclonal antibody or a control antibody of the same isotype. The sections were rinsed and allowed to react with goat antimouse $(\mathrm{IgG}+\mathrm{IgM})$ antiserum, followed by mouse peroxidase-antiperoxidase complex (Cappel, West Chester, PA), then the substrate, $3^{\prime}, 3^{\prime}$-diaminobenzidine.

DETECTION OF REARRANGEMENT OF T CELL RECEPTOR $\beta$ GENE

High molecular weight DNA was extracted from frozen cell pellets containing approximately $2 \times 10^{7}$ cells outgrown from the rheumatoid nodules. The DNA samples were digested with the restriction enzymes EcoRI or Hind III (Takarashuzo, Japan) and subjected to electrophoresis on $\mathbf{0 . 8 \%}$ agarose gels. After denaturation and neutralisation the DNA was transferred to nitrocellulose paper by the technique of Southern. ${ }^{20}$ Hybridisation to a randomly primed ${ }^{32} \mathrm{P}$ labelled DNA probe of the constant region of the $\mathrm{T}$ cell receptor gene was performed, followed by washing at the appropriate stringency, then autoradiography. Non-lymphoid control DNA was run simultaneously in order to identify the germ-line position of the gene examined.

STATISTICAL ANALYSIS

Statistical analysis was by Student's $t$ test.

\section{Results}

INTERLEUKIN 1 - LIKE ACTIVITY IN

SUPERNATANTS FROM CULTURED

RHEUMATOID NODULE TISSUE

When supernatants from cultured rheumatoid
Table 2 Activities of interleukin 1, interleukin 2, and interleukin 3 detected in the culture supernatants 24 hours after initiation of the culture from rheumatoid nodules. Values are mean (SE)

Activities $(U / \mathrm{ml})$ of

\begin{tabular}{llll} 
& Interleukin 1 & Interleukin 2 & Interleukin \\
\hline $\begin{array}{l}\text { Rheumatoid nodules } \\
(\mathrm{n}=9)\end{array}$ & $5.0(1 \cdot 2)$ & $0.2(0 \cdot 1)$ & $0.2(0 \cdot 1)$ \\
\hline
\end{tabular}

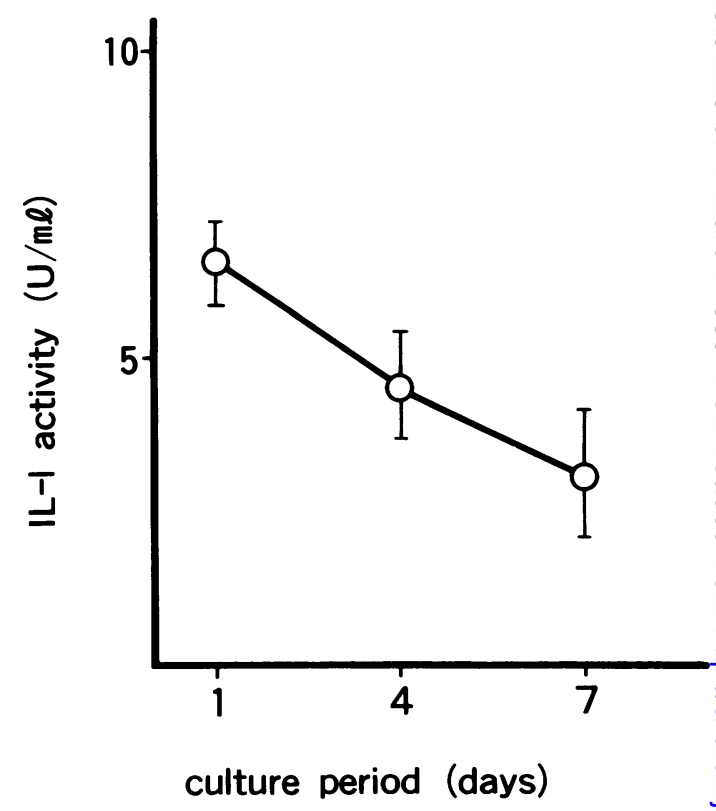

Fig. 1 Interleukin 1-like activity in the supernatant from $a$ cultured rheumatoid nodule one to seven days after the initiation of culture. The results of a representative experiment are shown. $I L-1=$ interleukin 1.

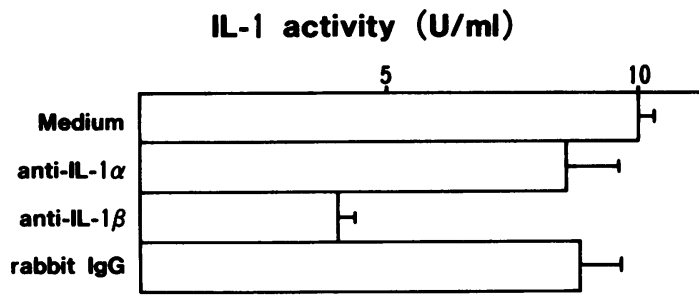

Fig. 2 The effect of anti-interleukin $1 \alpha$ or anti-interleukin $1 \beta$ antibody on interleukin 1-like activity in a supernatant from a cultured rheumatoid nodule. Results from a

representative experiment are shown. IL-1=interleukin 1 . 
nodule tissue were added to concanavalin A stimulated thymocyte cultures at dilutions of $1: 1$ to $1: 4$ there was a significant reduction in thymidine incorporation compared with cultures that had higher dilutions (1:8 or higher) of the same supernatants (data not shown). This suggested that inhibitory factor(s), including prostaglandins, might be contained in the supernatants from cultured rheumatoid nodule tissue. We therefore used supernatants with dilutions higher than $1: 8$ to test for interleukin 1 like activity.

Supernatants from cultured rheumatoid nodule tissue harvested on day 1 of culture induced significant proliferation of thymocytes stimulated with a suboptimal dose of concanavalin A $(5.0(1.2) \mathrm{U} / \mathrm{ml}$, mean (SE)) (Table 2). This activity was greater on day 1 of culture than on days 4 or 7 (Fig. 1). In addition, there was a tendency for this activity to be more pronounced in 'fresh' nodules-that is, 6.4 (1.0) $\mathrm{U} / \mathrm{ml}$ from fresh nodules (duration $<8$ weeks) $v$ 4.0 (1.0) $\mathrm{U} / \mathrm{ml}$ from 'old' nodules (duration $>3$ months) $(\mathrm{p}<0.01)$. Interleukin 1 activity was confirmed by growth inhibition assay using the melanoma cell line A375. Thus supernatants from day 1 of culture of rheumatoid nodule tissue significantly inhibited proliferation of the melanoma cell line $(13.8(2.5) \mathrm{U} / \mathrm{ml}$, mean (SE)). Furthermore, the interleukin 1-like activity in the supernatants was not blocked by anti-interleukin $1 \alpha$ antibody. It was significantly inhibited by anti-interleukin $1 \beta$ anti-
Pathophysiology of the rheumatoid nodule

body (up to $75 \%$ ), but not by normal rabbit $\mathrm{IgG}$, indicating that most of the interleukin 1-like activity could be ascribed to the interleukin $1 \beta$ molecule (Fig. 2). By contrast, neither interleukin 2 nor interleukin 3 activity was detected in the supernatants from any of the culture samples tested.

PROSTAGLANDIN E 2 IN SUPERNATANTS

FROM CULTURED RHEUMATOID NODULE

T IS S U E

Supernatants from cultured rheumatoid nodule tissue contained considerable amounts of prostaglandin $E_{2}$ (3650 (SE 1524) pg/ml), suggesting that prostaglandin $\mathrm{E}_{2}$ is spontaneously produced in rheumatoid nodules. There was no correlation between the amount of prostaglandin $E_{2}$ in the supernatants and interleukin 1 activity, and duration of rheumatoid nodules.

\section{SURFACE ANTIGENS OF CELLS OUTGROWN}

FROM RHEUMATOID NODULES

When fresh rheumatoid nodules were minced and pieces of these tissues were cultured, round mononuclear cells appeared around the tissues forming colonies (Fig. 3). These cells were relatively large in size and had small round nuclei with large cytoplasms.

We therefore examined their surface antigens using indirect immunostaining. Results showed that these cells strongly expressed HLA-DR antigens

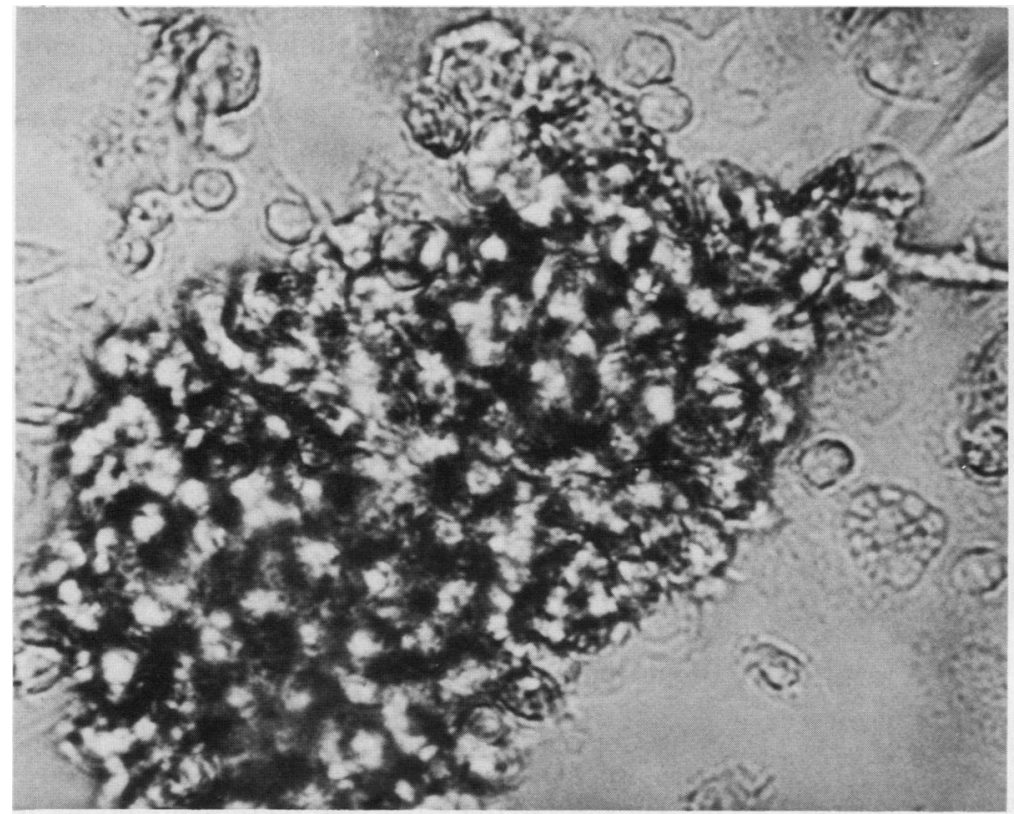

Fig. 3 A colony forming around tissue biopsied from a rheumatoid nodule. 
both in their cytoplasms and on their surfaces (Fig. 4). They also bore CD14 antigens on their surfaces. None of the $\mathrm{T}$ cell or $\mathrm{B}$ cell differentiation antigens so far tested was demonstrated, however. CD11b (Mo1) antigens were weakly detected. These results suggest that these cells may belong to the macrophage lineage (Table 3 ).

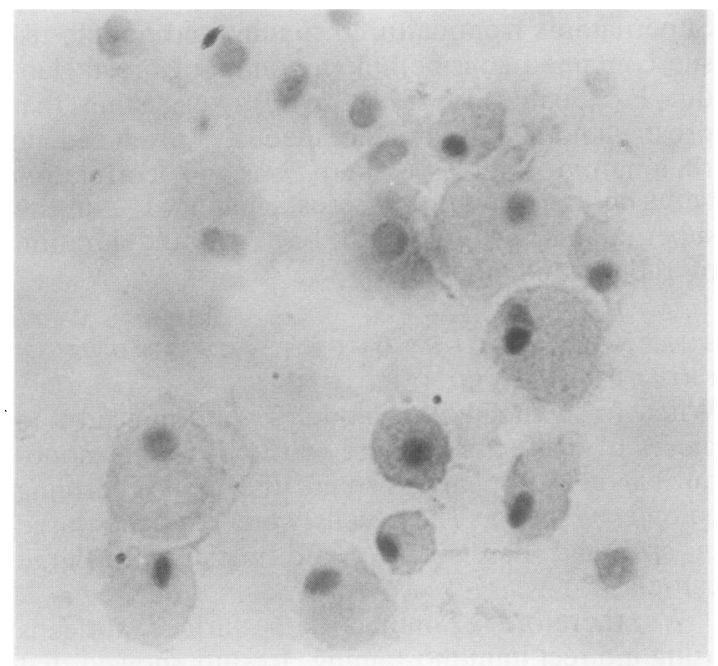

Fig. 4a

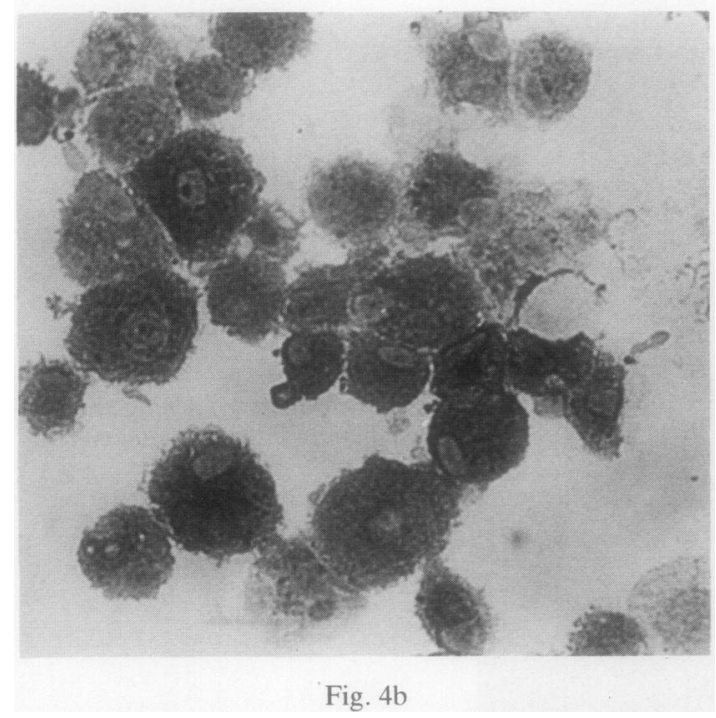

Fig. 4 Immunohistochemical analysis of cells outgrown from a rheumatoid nodule. (a) Staining with irrelevant mouse IgG; (b) staining with anti-HLA-DR antibody. Most of the cells are stongly reactive with anti-HLA-DRantibody.
Table 3 Surface antigens of cells outgrown from rheumatoid nodules

\begin{tabular}{|c|c|c|c|}
\hline HLA-DR & $(+)$ & CD4 & $(-)$ \\
\hline CD14 & $(+)$ & CD8 & $(-)$ \\
\hline CD11b & $(+)$ & CD20 & $(-)$ \\
\hline CD3 & $(-)$ & CD21 & $(-)$ \\
\hline
\end{tabular}

Cells were stained by various monoclonal antibodies as described in the 'Patients and methods' section.

RES PONSIVENESS OF CELLS OUTGROWN FROM RHEUMATOID NODULES IN VITRO We next studied the responsiveness of these cells to various stimuli in a proliferation assay. These cell ${ }^{\infty}$ did not synthesise DNA in vitro by responding to any of the stimuli tested: phytohaemagglutinin concancavalin A, S aureus Cowan I, and interleuking 2 (data not shown). Further, they did not spon=taneously incorporate tritiated thymidine. These data indicate that these cells may not be lymphocytic대 in origin.

PRODUCTION OF INTERLEUKIN 1 - LIKE

FACTOR BY CELLS IN VITRO

When these cells were collected and cultured in vitro $\left(5 \times 10^{5}\right.$ cells/well $)$ they spontaneously elaborated an interleukin 1-like factor. Thus supernatants from these cultured cells supported a proliferation of concanavalin A stimulated thymocytes (5.0 (1.2) $\mathrm{U} / \mathrm{ml}$ ) and inhibited growth of the A375 melanoma cell line $(10 \cdot 0(2 \cdot 6) \mathrm{U} / \mathrm{ml})$. This activity peaked on day 1 of culture and gradually declined on sub sequent days. This interleukin 1-like activity was. also neutralised by anti-interleukin $1 \beta$ antibody (data not shown). No other cytokine activity including that of interleukin 2 and interleukin 3, was. detected in these supernatants.

REARRANGEMENT OF T CELL RECEPTOR $\beta$

CHAIN GEN E

DNA from circulating granulocytes was used non- $T$ cells to define the normal germ-line arrange ment of the $T$ cell receptor $\beta$ chain gene. Whe $\mathrm{P}$ DNA from cells outgrown from a rheumatoigh nodule was studied it manifested $T$ cell $\beta$ genes in the germ-line configuration. No rearranged band was observed (data not shown). These data sug gested that the cells obtained from rheumatoif nodules were not of $\mathrm{T}$ cell origin.

\section{Discussion}

Subcutaneous rheumatoid nodules are one of the extra-articular symptoms seen in rheumatoid arthris tis. They are frequently found on pressure points a 
bony prominences and are associated with seropositivity in patients with rheumatoid arthritis. The pathogenesis of rheumatoid nodules remains to be elucidated, however.

We found both interleukin 1 like activity and prostaglandin $E_{2}$ in supernatants from cultured rheumatoid nodule tissue. Interleukin 1 like activity was confirmed by both thymocyte proliferation assay and growth inhibition assay using a melanoma cell line. This activity was significantly inhibited by antihuman interleukin 1 antibodies, especially by the antibody to recombinant interleukin $1 \beta$. Cells producing interleukin 1 activity in the nodules seem to be monocytic in origin. They responded neither to $\mathrm{T}$ cell nor to $\mathrm{B}$ cell mitogens and expressed CD14 and HLA-DR antigens on their surfaces. In addition, these cells showed the germ-line configuration of a $\mathrm{T}$ cell receptor gene, indicating that they are not of $\mathrm{T}$ cell origin. These cells have a phagocytic function (data not shown). Hedfors $e t$ al, using an immunohistochemical technique, showed that cells within the palisading layer were phenotypically 'macrophage-like'. ${ }^{21}$ Other investigators have also reported that rheumatoid nodules are composed largely of HLA-DR ${ }^{+}$macrophages. ${ }^{22}$ Furthermore, Palmer et al recently showed that the great majority of palisade cells in rheumatoid nodules express exclusively mononuclear phagocyte phenotypes. ${ }^{23}$ Our present study confirmed their results. We are currently examining the functions of these cells-for example, their ability to present antigens to $\mathrm{T}$ cells. It is possible that interleukin 1 produced locally by these cells induces the proliferation of fibroblasts, ${ }^{24}$ which in turn promotes palisade formation in the middle layer of rheumatoid nodules. The signal(s) for interleukin 1 production by these cells are not known at present, but they could be sent out by $T$ cells infiltrating the outer layer of rheumatoid nodules. Interleukin 1 could also stimulate synovial cells or fibroblasts to produce collagenase and prostaglandin $\mathrm{E}_{2},{ }^{9}$ possibly causing central necrosis in the inner layer of rheumatoid nodules, as Harris speculated. ${ }^{3}$

Using both organ culture ${ }^{7}$ and cloned synovial cells, ${ }^{25}$ we have shown that interleukin 1 like factor is produced in rheumatoid synovium. Collectively, three morphologically different cells were cloned from rheumatoid synovium-dendritic cells, macrophage-like cells, and fibroblast-like cells-all of which spontaneously elaborated interleukin 1 like factor(s) in culture. ${ }^{3}$ Furthermore, a significant amount of this activity was detected in the supernatants of cultures of biopsied rheumatoid synovium. The activity correlated well with the vascularity of the tissue as shown by arthroscopy, bony destruction as observed by $x$ ray films, and the expression of HLA-DR antigen on proliferating synovial cells. ${ }^{7}$ In addition, one of our collaborators recently found that cloned rheumatoid synovial cells, especially macrophage-like cells and dendritic cells, spontaneously produced prostaglandin $E_{2}$ in culture (Sasano, Goto, Nishioka, unpublished data). This, together with our present data, indicates that interleukin 1 and prostaglandin $E_{2}$ may be strongly involved in both the pathogenesis of synovitis and the formation of rheumatoid nodules in rheumatoid arthritis.

This study is the first to look at the production of cytokines by rheumatoid nodules in an attempt to shed light on their pathogenesis. We are currently studying the cascades or networks of cytokine production in both rheumatoid nodules and rheumatoid synovium.

We are grateful to Japan Scientific Instrument Company for providing monoclonal antibodies, to Ms Junko Hirose and Ms Hiroko Inoue for their technical assistance, and Ms Hiromi Kishi for her superb secretarial work. This work was partly supported by a grant-in-aid from the Ministry of Health and Welfare, Japan.

\section{References}

1 Kaye B R, Kaye R L, Bobrove A. Rheumatoid nodules. Review of the spectrum of associated conditions and proposal of a new classification, with a report of four seronegative cases. Am J Med 1984; 76: 279-92.

2 Hedfors E, Klareskog L, Lindblad S, Forsum U, Lindahl G. Phenotypic characterization of cells within subcutaneous rheumatoid nodules. Arthritis Rheum 1983; 26: 1333-9.

3 Harris E D. A collagenolytic system produced by primary cultures of rheumatoid nodule tissue. J Clin Invest 1972; 51: 2973-6.

4 Greenberg A J. Rheumatoid nodules. Journal of the American Podiatry Association 1982; 72: 84-8.

5 Fukase M, Koizumi F, Wakaki K. Histopathological analysis of sixteen subcutaneous rheumatoid nodules. Acta Pathol Jpn 1980; 30: 871-82.

6 Panayi G S, Wooley P, Batchelor J R. Genetic basis of rheumatoid disease: HLA antigens, disease manifestations, and toxic reactions to drugs. $\mathrm{Br}$ Med $J$ 1978; ii: $1326-8$.

7 Miyasaka N, Nakamura T, Russel I J, Talal N. Interleukin-2 deficiencies in rheumatoid arthritis and systemic lupus erythematosus. Clin Immunol Immunopathol 1984; 31: 109-17.

8 Dinarello C A. Interleukin-1 and the pathogenesis of the acute-phase response. $N$ Engl J Med 1984; 311: 1413-8.

9 Dayer J M, Krane S M, Russel G G, Robinson D R. Production of collagenase and prostaglandins by isolated adherent rheumatoid synovial cells. Proc Natl Acad Sci USA 1976; 73: 945-9.

10 Miyasaka N, Sato K, Goto M, et al. Augmented interleukin-1 production and HLA-DR expression in the synovium of rheumatoid arthritis-possible involvement in joint destruction. Arthritis Rheum 1988; 31: 480-6.

11 Ropes M W, Bennett G A, Cobb S, Jacox R, Jessar R A. 1958 revision of diagnostic criteria of rheumatoid arthritis. Bull Rheum Dis 1985; 9: 175-6.

12 Lachman L B, Hacker M P, Blyden G T, Handschumacher R E. Preparations of lymphocyte-activating factor from continuous murine macrophage cell line. Cell Immunol 1977; 34: 416-9.

13 Matsushima K, Procopio A, Abe H, Scala G, Ortaldo J, Oppenheim J. Production of interleukin-1 activity by normal 
human peripheral blood B lymphocytes. J Immunol 1985; 135: 1132-6.

14 Nishida T, Nishino N, Takano M, et al. cDNA cloning of IL-1a and IL-1 $\beta$ from mRNA of U937 cell line. Biochem Biophys Res Commun 1987; 143: 345-52.

15 Tanaka K, Ishikawa E, Ohtomo Y, Hirai Y. Sandwich enzyme

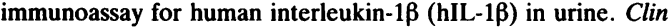
Chim Acta 1987; 166: 237-46.

16 Miyasaka N, Murota N, Yamaoka K, et al. Interleukin-2 defect in the peripheral blood and the lung in patients with Sjögren's syndrome. Clin Exp Immunol 1986; 65: 497-505.

17 Koyasu S, Nakauchi H, Kitamura K, et al. Production of interleukin 3 and $\alpha$-interferon by an antigen-specific mouse suppressor T cell clone. J Immunol 1985; 134: 3130-4.

18 Gillis S, Ferm M M, Ou W. T cell growth factor: parameters of production and a quantitative microassay for activity. $J$ Immunol 1982; 120: 2127-32.

19 Ciabattoni G, Pugliese F, Spaldi M, Cinotti G A, Patrono C. Radioimmunoassay of prostaglandin $\mathrm{E}$ and $\mathrm{F}$ in human urine. $J$ Endocrinol Invest 1979; 2: 173-7.
20 Southern, E M. Detection of specific sequences among DNA fragments separated by gel electrophoresis. J Mol Biol 1975; 98 ग 503-17.

21 Hedfors E, Klareskog L, Lindblad S, Forsum U, Lindahl GC Phenotypic characterization of cells within subcutaneous rheumatoid nodules. Arthritis Rheum 1983; 26: 1333-9.

22 Duke O, Hobbs S, Panayi G, Poulter L, Rasker J, Janossy G. AФ combined immunohistological and histochemical analysis of lymphocyte and macrophage subpopulations in the rheumatoids nodule. Clin Exp Immunol 1984; 56: 239-46.

23 Palmer D, Hogg N, Highton J, Hessian P, Denholm I: Macrophage migration and maturation within rheumatoid nodules. Arthritis Rheum 1987; 30: 729-36.

24 Schmidt J A, Mizel S B, Cohen D, Green I. Interleukin 1, को potential regulator of fibroblast proliferation. J Immunol $1982 \%$ 128: $2177-82$.

25 Goto M, Sasano M, Yamanaka H, et al. Spontaneous produc $\stackrel{0}{9}$ tion of an interleukin-1-like factor by cloned rheumatoidu synovial cells in long-term culture. J Clin Invest 1987; 80 N 786-96. 